\title{
Pemodelan dan Simulasi Urutan Pengelasan Bilah Roda Traktor Berbasis Metoda Elemen Hingga
}

\author{
Suryadiwansa Harun dan Yanuar Burhanuddin \\ Jurusan Teknik Mesin, Fakultas Teknik, Universitas Lampung, Bandar Lampung \\ E-mail: harun@unila.ac.id
}

\begin{abstract}
ABSTRAK
Tulisan ini membahas pemodelan dan simulasi pengelasan berbasis metode elemen hingga (MEH) untuk memprediksi distorsi pengelasan bilah roda traktor. Dua pemodelan MEH dibutuhkan untuk mendapatkan model distorsi pengelasan, yaitu termal dan elasto-plastis. Pengaruh termal pengelasan diasumsikan sebagai gaya tendon dijadikan masukan pada analisis elasto-plastik. Hasil simulasi distorsi pengelasan diverifikasi dengan menggunakan data eksperimen pengelasan. Hasil verifikasi menunjukkan kemiripan bentuk deformasi pengelasan antara simulasi dan eksperimen. Deviasi nilai distorsi displacement antara simulasi dan eksperimen adalah kecil. Karenanya, simulasi pemodelan deformasi pengelasan menggunakan $\mathrm{MEH}$ termal elasto-plastis dapat digunakan untuk memprediksi distorsi pengelasan bilah roda traktor. Berdasarkan hasil simulasi, bentuk distorsi displacement radial dan aksial akibat pengelasan bilah dengan urutan serial adalah lebih besar dibandingkan bentuk distorsi akibat pengelasan bilah dengan urutan seperti direkomendasikan. Setelah simulasi pengelasan sejumlah 16 bilah roda traktor, nilai distorsi displacement akibat urutan pengelasan bilah serial diprediksi sebesar $3,393 \mathrm{~mm}$, dimana adalah lebih besar dibandingkan nilai 1,440mm akibat urutan pengelasan bilah yang direkomendasikan.
\end{abstract}

Kata kunci: Pengelasan, distorsi, bilah roda traktor, urutan pengelasan, dan metode elemen hingga.

\begin{abstract}
This paper discusses the modelling and simulation of welding process based on the finite element method (FEM) in order to predict the welding distortion of tractor wheel blades. Two FEM modellings are needed to obtain the welding distortion models, namely thermal and elastoplastic. The effect of welding thermal is assumed as tendon force and to be used as input of the analysis of elasto-plastic modelling. Welding distortion simulation results were verified using the experimental data. The verification results have shown similar shape of the welding deformation between simulations and experimental. Also, deviation value of displacement distortion between simulation and experimental is small. Hence, the simulation of welding deformation modelling using thermal elasto-plastic FEM can be used to predict the welding distortion of tractor wheel blades. Based on simulation results, the shape of radial and axial displacement distortion due to welding the blade with serial sequence was larger than that of the shape distortion due to welding of the blade with a recommended sequence. After welding simulation of those of 16 wheels tractor blades, the predicted value of displacement distortion due to welding of the blade with serial sequence is equal to $3,393 \mathrm{~mm}$, which was larger than that of $1,440 \mathrm{~mm}$ due to welding of the blade with recommended sequence.
\end{abstract}

Keywords: Welding, Distortion, Tractor Wheel Blade, Welding Sequence, and Finite Element Method.

\section{PENDAHULUAN}

Distorsi merupakan masalah yang tidak dapat dihindari pada pengelasan suatu struktur yang terbentuk dari logam. Ketika struktur logam dilakukan proses pengelasan, sebuah siklus termal yang cepat dari proses pemanasan dan pendinginan terbentuk sepanjang sambungan las dikarenakan pergerakan sumber panas [1]. Siklus termal yang cepat akan membuat material yang dilelehkan mengalami kontraksi sehingga terjadi penyusutan simultan ke segala arah. Selain itu, karena distribusi suhu yang tidak seragam selama siklus termal akan menimbulkan regangan yang tidak sama. Regangan yang tidak sama ini disebabkan karena perubahan dimensi yang dikaitkan dengan pengerasan logam 
las, transformasi metalurgi dan deformasi plastik adalah merupakan sumber-sumber tegangan sisa dan distorsi

Keberadaan distorsi dan tegangan sisa pada hasil pengelasan akan mempunyai dampak yang tidak menguntungkan pada kinerja struktur las seperti ketidakakuratan dimensi dan struktur menjadi mudah patah. Ini tentu saja merugikan baik pembuat maupun pemakai struktur tersebut. Keadaan yang demikian juga terjadi pada pengelasan bilah roda traktor di bengkel las Industri Kecil (IK) Logam, khususnya di Pringsewu, yang mana roda traktor yang dibuat para pekerja IK Logam masih berkualitas rendah (terjadi distorsi displacement aksial dan radial yang besar) [2]. Adanya distorsi yang melekat pada proses pengelasan menuntut ditemukan cara pengelasan yang benar. Salah satu motode yang dapat diaplikasikan untuk meminimalkan distorsi pengelasan adalah dengan menerapkan welding sequence (urutan pengelasan) [3]. Selama ini praktek urutan pengelasan bilah roda traktor didasarkan pengalaman empirik pemilik bengkel atau pekerja bengkel/ industri tersebut. Belum ada alasan teknik mengapa urutan pengelasan tersebut dipilih dan digunakan. Oleh sebab itu penelitian ini dilakukan untuk meneliti dampak urutan pengelasan bilah roda traktor terhadap distorsi pengelasan yang terjadi dan menyelidiki urutan pengelasan yang benar.

Untuk mengetahui efek urutan pengelasan pada bilah distorsi roda traktor perlu dibuat simulasi urutan pengelasan. Seiring dengan perkembangan teknologi simulasi $\mathrm{CAD} / \mathrm{CAE}$ menggunakan komputer, simulasi numerik urutan pengelasan berbasis metode elemen hingga adalah cara yang efektif untuk mensimulasikan proses perakitan bilah roda traktor. Metode Elemen Hingga (Finite Element Method, FEM) mampu melakukan analisis non-linear pada proses pengelasan yang memiliki bentuk yang kompleks dan kompetibel dengan perankat lunak Computer Aided Engineering (CAE) modern. Selain itu FEM juga mampu menganalisis distribusi perpindahan panas (kajian termal) serta kajian yang berhubungan perubahan bentuk material akibat adanya panas yang tidak seragam. Maka dari itu elemen hingga merupakan metode yang efektif untuk pemodelan dan simulasi proses pengelasan.

Pada saat sekarang ada beberapa model analitik termal proses pengelasan berbasis metode elemen hingga yang diketahui seperti yang dilakukan oleh Rosenthal et al. [4], Jeong et al. [5] dan Goldak et al. [6]. Dalam penelitian Rosenthal dan Jeong, sumber panas daerah lasan direpresentasikan oleh suatu bidang (2D). Metode ini digunakan hanya pada pelat yang tebalnya terbatas untuk sambungan lasan fillet. Walaupun metode ini dapat digunakan untuk memprediksi deformasi material akibat pengelasan, akan tetapi deformasi material yang diprediksi hanya dalam arah dua dimensi (2D). Sedangkan arah deformasi material akibat pengelasan sesungguhnya adalah tiga dimensi sehingga distorsi akibat deformasi material juga berpotensi terjadi dalam arah tiga dimensi. Oleh karena itu, Goldak melakukan penelitian tentang simulasi deformasi material dalam arah tiga dimensi (3D) untuk memprediksi distorsi pengelasan lebih akurat. Sejalan dengan itu, dalam penelitian ini deformasi akibat pengelasan disimulasikan dengan model elemen hingga 3D. Untuk memudahkan prosedur simulasi, simulasi numerik tidak-bergandeng digunakan. Pada simulasi tersebut dibutuhkan dua pemodelan elemen hingga yaitu termal transien dan elastoplastis. Hasil analisis pemodelan termal transien akan digunakan untuk analisis kedua (pemodelan elasto-plastis) bersama-sama dengan suhu yang bergantung kepada sifat mekanik bahan.

Pada penelitian ini pemodelan dan simulasi proses pengelasan bilah roda traktor menggunakan komputasi melalui SolidWorks (CAD) dan COSMOS (CAE). Hasil penelitian ini akan dijadikan acuan pada pengelasan blade (bilah) roda traktor khususnya oleh pekerja IK Logam di Pringsewu.

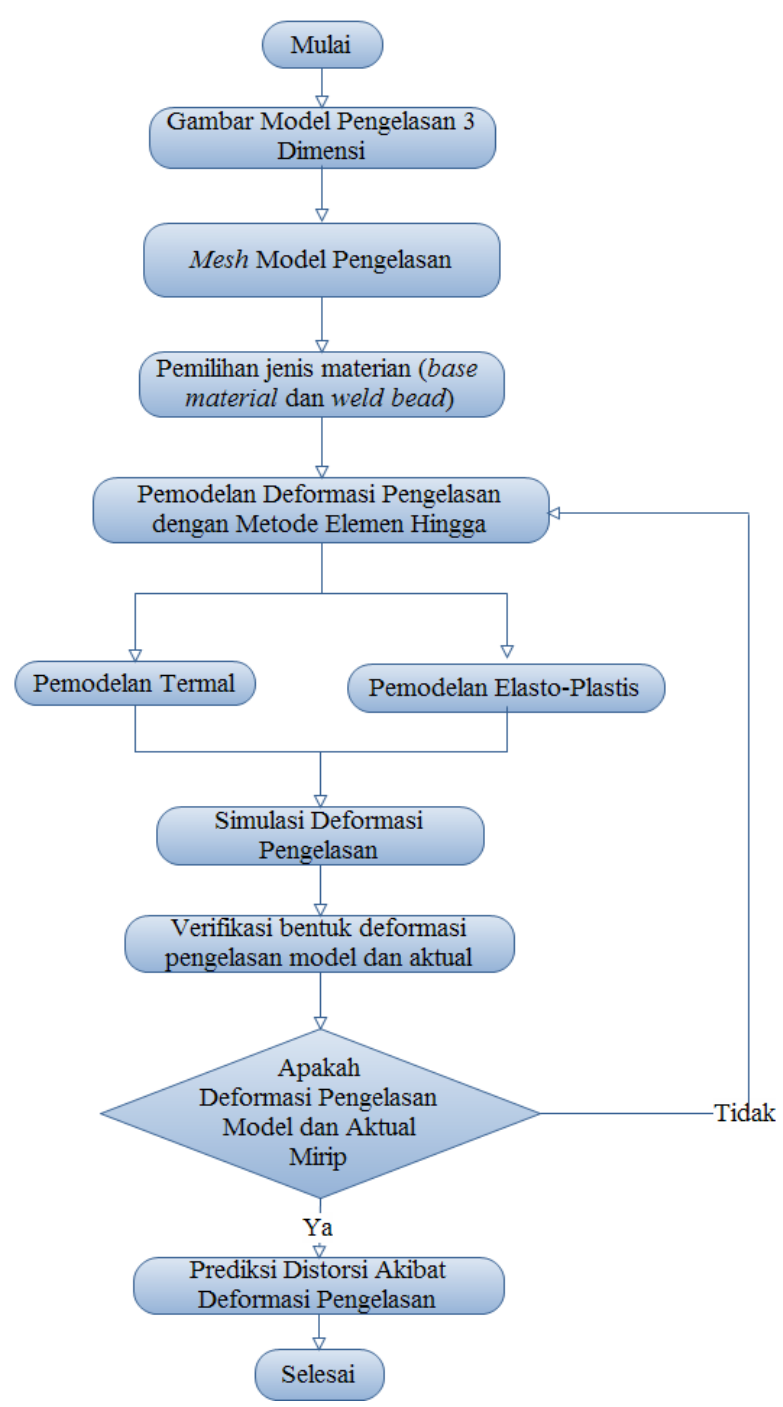

Gambar 1. Diagram Alir Pemodelan Deformasi Pengelasan 


\section{METODE PENELITIAN}

\section{Pemodelan Deformasi Pengelasan dengan Metode Elemen Hingga}

Diagram alir pemodelan deformasi pengelasan dapat dilihat pada gambar 1. Pemodelan dimulai dengan penggambaran bentuk model pengelasan dengan perangkat lunak SolidWorks. Setelah penggambaran bentuk model selesai dilakukan maka proses selanjutnya adalah pembuatan mesh. Setelah itu dilakukan pemilihan sifat material (material properties) yang digunakan yaitu material dasar (base material) dan titisan las (weld bead), di mana properties kedua material ini diasumsikan sama. Dalam penelitian ini dibutuhkan dua pemodelan elemen hingga untuk mendapatkan deformasi pengelasan, yaitu pemodelan termal dan elastoplastis. Kedua pemodelan tersebut menggunakan perangkat lunak CosmosWorks. Untuk memudahkan prosedur simulasi, simulasi numerik tidakbergandeng digunakan. Pada analisis tersebut, hasil analisis termal transien akan digunakan untuk analisis kedua bersama-sama dengan suhu yang bergantung kepada sifat mekanik bahan seperti koefisien ekspansi termal, modulus elastisitas, rasio Poisson, dan lain-lain. Kepadatan pada analisis elasto-plastik diasumsikan tetap. Hasil dari simulasi akan diverifikasi menggunakan eksperimen pada geometri benda dan parameter pengelasan yang sama untuk membangun korelasi secara kuantitatif antara simulasi finite element dan eksperimen.

\section{Model Termal Transien}

Analisis model elemen hingga tiga dimensi dari nonlinear aliran panas transien dari sumber panas pada daerah titisan las adalah diilustrasikan dalam Gambar 2. Perpindahan panas konduksi transient (unsteady) dalam elemen solid dan kondisi batas berupa kombinasi antara perpindahan panas konveksi dan radiasi pada bagian luar permukaan solid adalah ditentukan berdasarkan konstitusi perangkat lunak FEM COSMOSWorks yang digunakan dalam penelitian ini. Properties termal material adalah tergantung pada suhu masukan yang diukur dengan termokopel selama proses pengelasan.

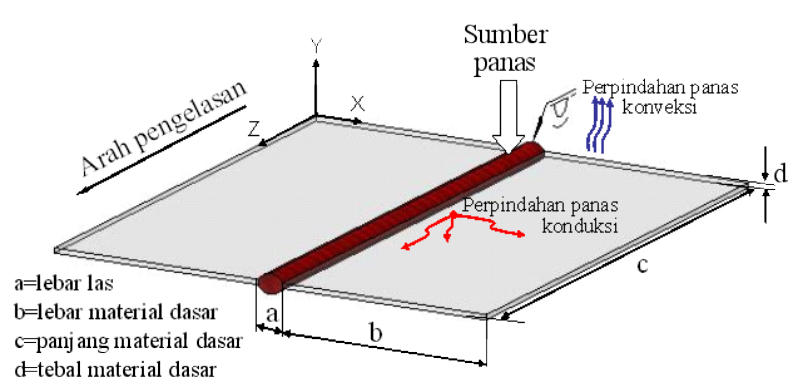

Gambar 2. Model Transien Termal

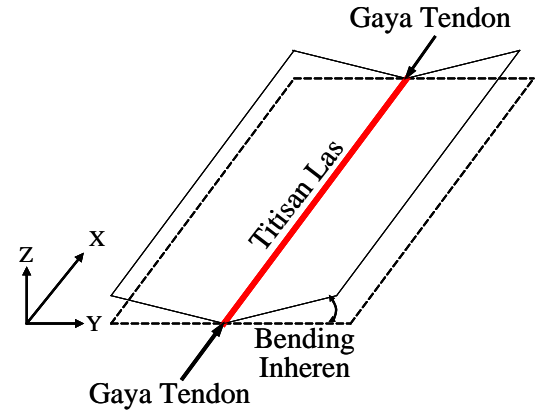

Gambar 3. Gaya Tendon pada Pengelasan

\section{Model Elasto-Plastis}

Murakawa [7] mengatakan deformasi dan tegangan sisa yang dihasilkan sepanjang pengelasan atau pemanasan garis disebabkan tegangan takkembali atau regangan melekat (hakiki) karena proses deformasi plastik. Oleh karena itu, deformasi dan tegangan sisa yang dihasilkan pada saat siklus termal dapat diprediksi dengan analisis elastik dimana regangan inheren (hakiki) dikenal sebagai regangan awal. Selanjutnya, untuk keringkasan dan kepraktisan prediksi, deformasi inherent-yang merupakan integral dari regangan inherent-dan gaya tendon dicari.

Dalam analisis elasto-plastis ini diasumsikan bahwa deformasi pengelasan terjadi akibat gayagaya pengerutan longitudinal atau tendon force, $F_{x}$ yang bereaksi pada suatu node dalam arah pengelasan seperti diilustrasikan dalam Gambar 3. Gaya tendon ini dapat diperoleh dengan persamaan sebagai berikut [7]:

$F_{x}=E h \delta_{x}^{*}$

di mana,

$\mathrm{E}=$ Modulus Young $\left(\mathrm{N} / \mathrm{m}^{2}\right)$

$\mathrm{h}=$ tebal pelat $(\mathrm{mm})$

Sedangkan $\delta_{x}^{*}$ adalah shrinkage arah longitudinal (arah pengelasan), dimana itu dapat dihitung dari persamaan sebagai berikut:

$\delta_{x}^{*}=\frac{1}{h} \int \varepsilon_{x}^{*} d y \cdot d z$

di mana,

$\varepsilon_{x}^{*}=$ Regangan hakiki (inheren strain) arah pengelas-

an (diperoleh dari analisis pemodelan termal)

$\mathrm{x}=$ koordinat dalam arah pengelasan

$\mathrm{y}=$ koordinat dalam arah transversal

$\mathrm{z}=$ koordinat dalam arah longitudinal

\section{HASIL DAN PEMBAHASAN}

Implementasi dan Verifikasi Secara Eksperimental

Simulasi Deformasi Pengelasan Tumpul (Jenis V)

Simulasi awal dengan bentuk pengelasan sederhana perlu dilakukan sebagai verifikasi pemo- 
delan. Pada penelitian ini model pengelasan sambungan tumpul (V) seperti dilihat pada gambar 4 disimulasikan deformasinya menggunakan FEM. Hasil dari proses meshing model geometri pengelasan dapat dilihat pada gambar 5. Sifat mekanik dan termal dari material Baja AISI 1020 yang digunakan dalam simulasi ini dapat dilihat pada table 1 . Untuk mensimulasikan distribusi regangan (strain) akibat pemanasan pada daerah penampang lasan, maka suhu pada daerah lasan dimasukkan sebesar $1364^{\circ} \mathrm{C}$, dimana itu diperoleh dari pengukuran suhu pengelasan aktual menggunakan termokopel yang disambungkan dengan Termometer Infrared. Hasil simulasi regangan termal (thermal strain) pengelasan tumpul dapat dilihat pada Gambar 6. Dari Gambar 6 terlihat bahwa regangan maksimum material akibat pemanasan adalah 0,014, dimana itu terletak pada bagian tengah titisan las. Dalam rangka simulasi deformasi pengelasan, regangan maksimum ini akan digunakan sebagai parameter masukan untuk mendapatkan gaya tendon (tendon force). Tabel 2 memperlihatkan parameter masukan yang lain yang digunakan untuk menghitung gaya tendon. Berdasarkan perhitungan menggunakan persamaan 1 , gaya tendon yang diperoleh adalah $350 \mathrm{kN}$, dimana gaya ini digunakan sebagai parameter masukan pada pemodelan elasto-plastis untuk mensimulasikan deformasi pengelasan.

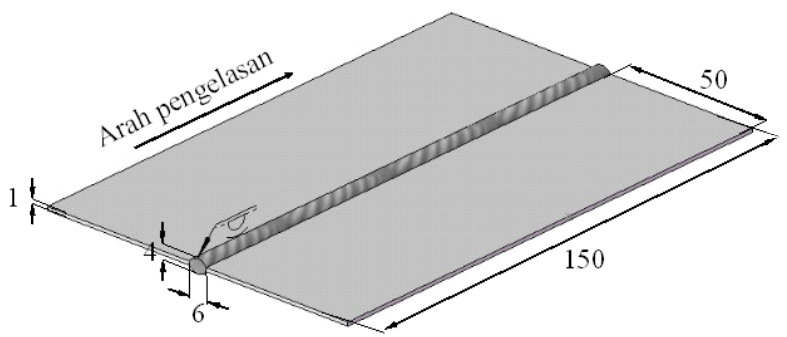

Gambar 4. Model Pengelasan Tumpul

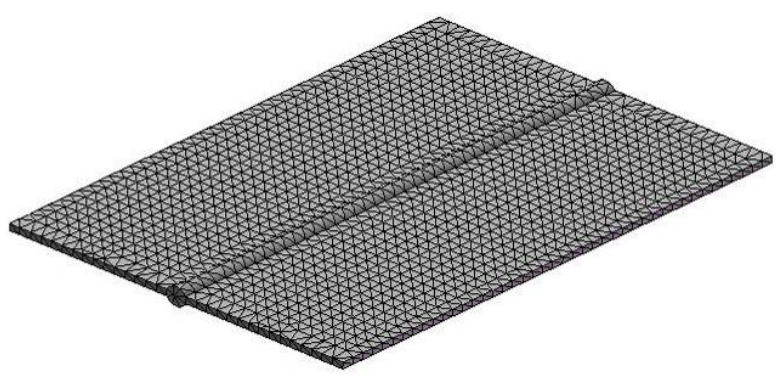

Gambar 5. Meshing Model Pengelasan Tumpul

Tabel 1. Sifat mekanik dan termal dari material Baja AISI 1020

\begin{tabular}{ll}
\hline Material & AISI 1020 \\
\hline Tensile Strength & $4.20507 \times 10^{8} \mathrm{~N} / \mathrm{m}^{2}$ \\
Yield Strength & $3.5157 \times 10^{8} \mathrm{~N} / \mathrm{m}^{2}$ \\
Mass Density & $7900 \mathrm{~kg} / \mathrm{m}^{3}$ \\
Thermal Expantion Coeficient & $1.5 \times 10^{-5} /$ Kelvin \\
Thermal Conductivity & $47 \mathrm{~W} /(\mathrm{m} . \mathrm{K})$ \\
Spesific Heat & $420 \mathrm{~J} /(\mathrm{kg} . \mathrm{K})$ \\
\hline
\end{tabular}

Tabel 2. Parameter masukan gaya tendon

\begin{tabular}{ll}
\hline Initial Strain & 0,014 \\
Tebal plat & $1 \mathrm{~mm}$ \\
Modulus Elastis & $2 \times 10^{11 \quad ~ N} / \mathrm{m}^{2}$ \\
Panjang Plat & $150 \mathrm{~mm}$ \\
Tebar plat & $50 \mathrm{~mm}$ \\
\hline
\end{tabular}

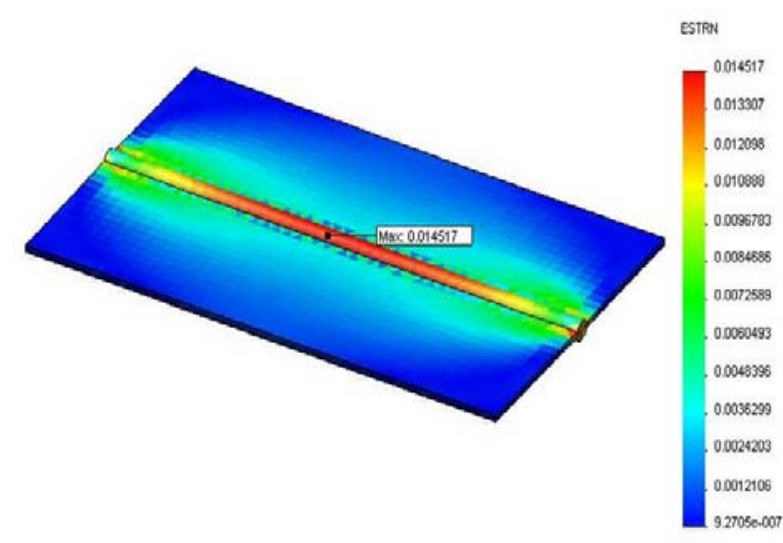

Gambar 6. Simulasi Pemodelan Initial Strain

\section{Verifikasi Model}

Hasil simulasi pemodelan selanjutnya diverifikasi dengan menggunakan eksperimen pengelasan pada benda kerja dan parameter pengelasan yang serupa dengan pemodelan. Eksperimen pengelasan dengan shielded metal arc welding dilakukan pada pengelasan sambungan tumpul material baja karbon rendah (AISI 1020) dengan ketebalan $1 \mathrm{~mm}$. Parameter pengelasan yang digunakan dalam eksperimen dapat dilihat pada Tabel 3. Gambar 7 memperlihatkan bentuk deformasi pengelasan dari model dan hasil eksperimen. Dari gambar ini terlihat bahwa bentuk deformasi pengelasan antara hasil pemodelan dan eksperimen adalah mirip. Bentuk distorsi yang terjadi terlihat ada dua jenis, yaitu longitudinal shrinkage dan longitudinal bending. Selain itu, distorsi perpindahan posisi (displacement) akibat deformasi pengelasan dalam arah transversal dapat dilihat pada Gambar 10. Dari gambar ini terlihat bahwa grafik distorsi displacement antara simulasi dan eksperimen mempunyai kecenderungan yang sama. Deviasi nilai displacement antara hasil simulasi dan eksperimen adalah kecil. Berdasarkan hasil di atas dapat digunakan sebagai alasan bahwa simulasi pengelasan dapat membantu untuk memprediksi distorsi pengelasan

Tabel 3. Parameter eksperimen pengelasan tumpul

\begin{tabular}{ll}
\hline Diameter Elektoda & $2,8 \mathrm{~mm}$ \\
Arus (I) & 20 Ampere \\
Voltage (V) & 220 Votl \\
Suhu Pengelasan & $1364^{\circ} \mathrm{C}$ \\
\hline
\end{tabular}



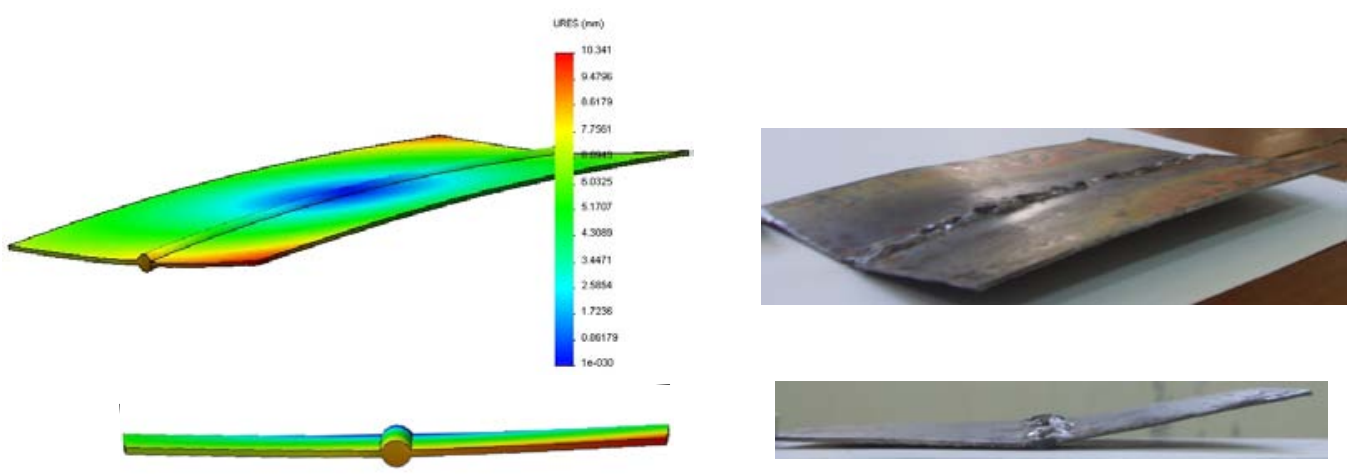

Longitudinal shrinkage

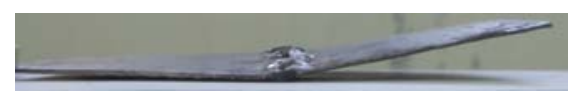

.

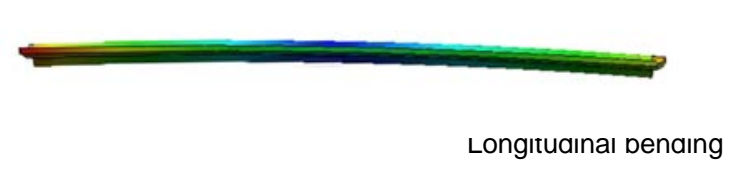

(a) Simulasi

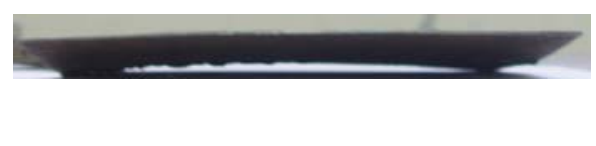

(b) Aktual

Gambar 7. Deformasi Bentuk akibat Pengelasan

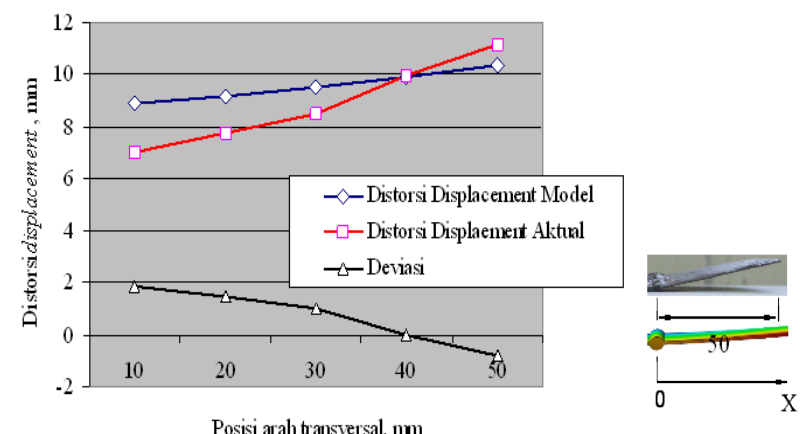

Gambar 8. Distorsi Perpindahan Posisi (displacement) arah Transversal

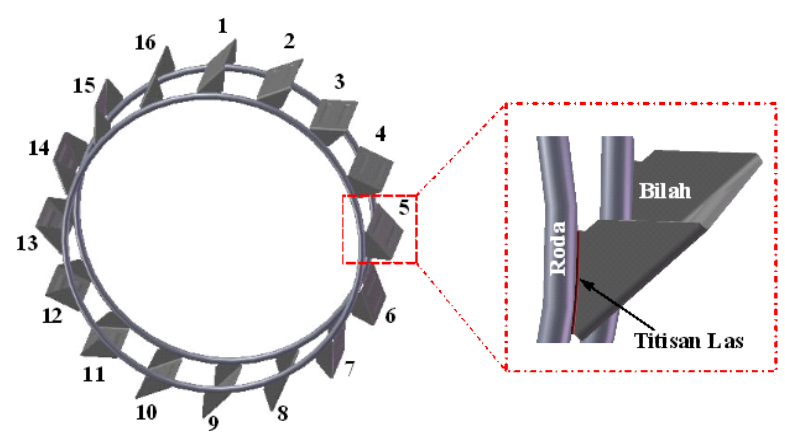

Gambar 9. Urutan Pengelasan Bilah Roda Traktor Secara Sekuensial

\section{$\underline{\text { Studi Kasus Simulasi Deformasi Pengelasan Bilah }}$} Roda Traktor

Dalam rangka meminimalkan terjadinya distorsi pengelasan roda traktor yang meliputi distorsi displacement arah aksial maupun radial, maka pada penelitian dilakukan simulasi pemodelan urutan pengelasan bilah. Perbandingan antara distorsi hasil simulasi urutan pengelasan bilah yang umumnya dilakukan oleh IK Logam (urutan seri) dan diatur urutannya dilakukan. Selain itu hasil simulasi akan diverifikasi dengan hasil pengukuran distorsi displacement roda traktor secara aktual.

\section{$\underline{\text { Simulasi Pemodelan Urutan Pengelasan Serial }}$}

Urutan pengelasan bilah roda traktor yang umumnya diterapkan oleh bengkel IK Logam ini adalah urutan pengelasan berurutan (sekuensial atau serial) tanpa pencekaman (free condition). Gambar model urutan pengelasan sekuensial dapat dilihat pada Gambar 11. Pengelasan dimulai dengan pemasangan bilah kesatu, disusul dengan bilah kedua dan seterusnya dalam arah jarum jam.

Untuk melakukan simulasi deformasi pengelasan, perlu adanya masukan (input) gaya-gaya yang ditimbulkan oleh pengerutan. Pengerutan yang diperhatikan adalah pengerutan dalam arah longitudinal lasan. Akibat pengerutan longitudinal tersebut timbul gaya pengerutan longitudinal atau yang disebut dengan gaya tendon, dimana untuk kasus ini besar gaya yang diberikan adalah $30 \mathrm{kN}$. Gaya tendon diasumsikan seragam sepanjang lasan. Gaya tendon akan menekan struktur las pada ujung-ujung lasan. Pembebanan pada struktur terlas dan distorsi yang terjadi dapat dilihat pada gambar 10. Selain itu, gambar 10 tersebut juga menunjukkan prediksi distorsi maksimum dalam arah aksial yang terjadi akibat pengelasan sampai bilah ke-4 adalah 4,803 $\mathrm{mm}$. 


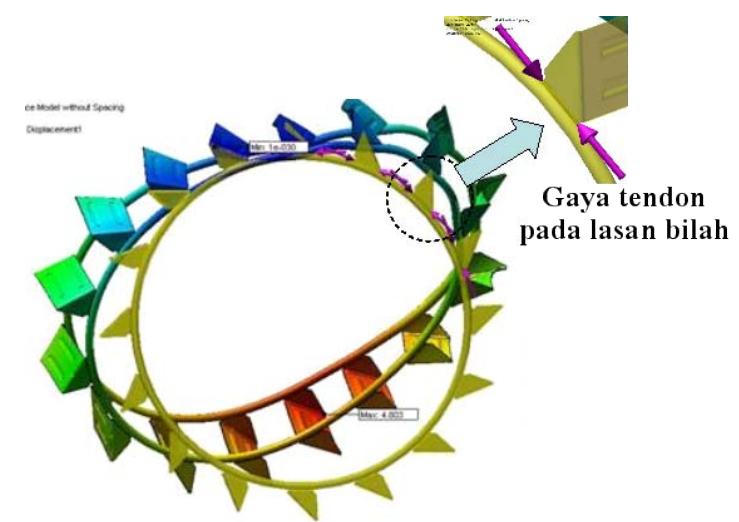

(a) Pembebanan gaya tendon pada ujung lasan sampai bilah ke-4

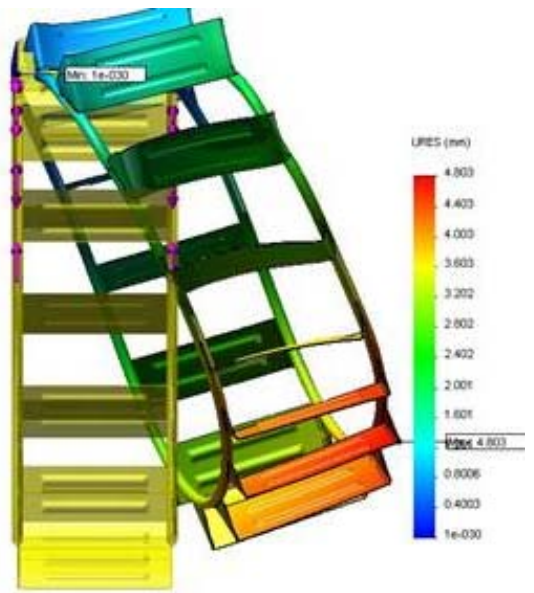

(b) Distorsi aksial roda traktor akibat urutan pengelasan sekuensial

Gambar 10. Pembebanan pada Struktur Las dan Distorsi Aksial yang Terjadi

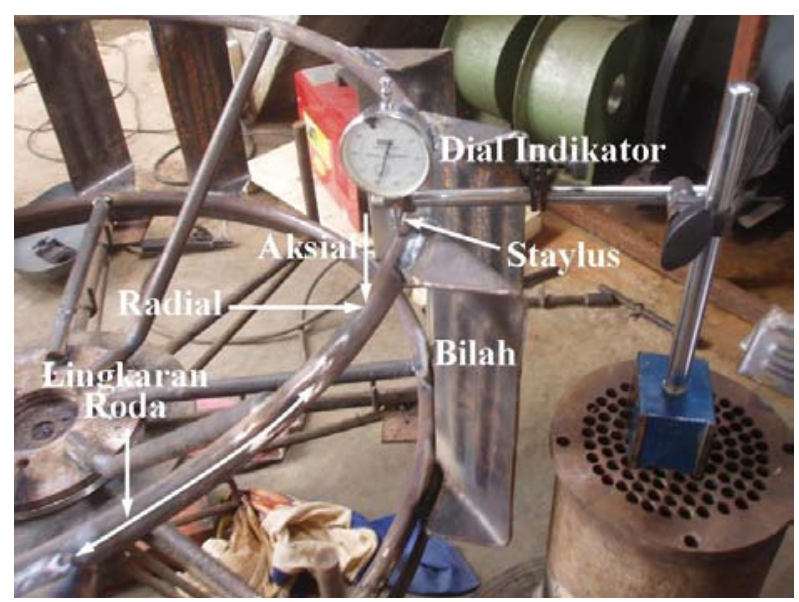

Gambar 11. Set-up Pengukuran Distorsi Radial dan Aksial Roda Traktor

\section{Verifikasi dan Pembahasan}

Untuk memastikan ketepatan prediksi distorsi pengelasan sekuensial secara simulasi maka perlu dilakukan pengukuran terhadap struktur yang sebenarnya. Gambar 11 memperlihatkan set-up pengukuran distorsi displacement roda traktor akibat pengelasan dengan menggunakan alat ukur dial indikator. Hasil simulasi distorsi pengelasan seri bilah kesatu dan sampai kedelapan (lihat Gambar 12.a dan b) diverifikasi dengan hasil pengukuran distorsi displacement aktual. Hasil simulasi dan pengukuran distorsi aksial pengelasan serta deviasinya dapat dilihat pada Tabel 4 dan Gambar 13.

Dari Tabel 4 dan Gambar 13.a dapat dilihat bahwa distorsi displacement aksial terbesar terjadi pada daerah bilah nomor 8 sampai 10 ketika pengelasan bilah pertama dilakukan. Kecenderungan yang sama juga diperoleh ketika pengelasan sampai bilah kedelapan seperti dilihat pada gambar 13.b. Hal ini mengesahkan asumsi bahwa distorsi pengelasan pada benda bulat biasanya terjadi pada daerah berseberangan. Secara teoritik apabila benda bulat mengalami pemuaian maka bentuk benda tersebut menjadi lonjong, sehingga penyimpangan terbesar terletak pada titik berseberangan. Demikian hal yang terjadi pada pengelasan bilah kesatu sampai bilah kedelapan roda traktor, distorsi displacement aksial terbesar tejadi pada titik yang berseberangan dengannya.

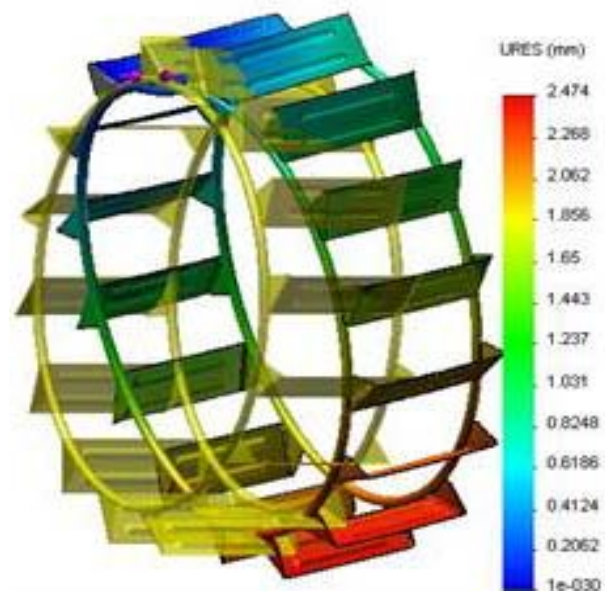

(a) Pengelasan bilah kesatu

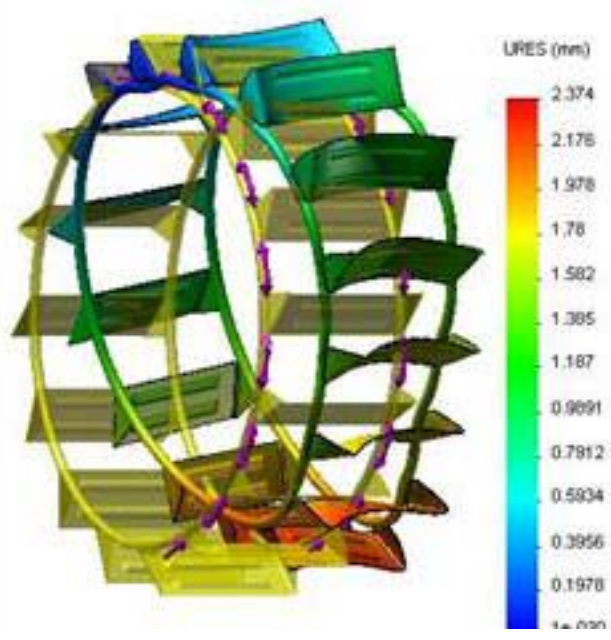

(b) Pengelasan seri sampai bilah kedelapan

Gambar 12. Simulasi Distorsi Pengelasan Bilah Kesatu sampai Kedelapan 
Tabel 4. Hasil simulasi dan pengukuran distorsi displacement aksial pengelasan sekuensial bilah roda traktor

\begin{tabular}{|c|c|c|c|c|c|c|}
\hline \multirow{2}{*}{ Bilah ke } & \multicolumn{3}{|c|}{ Distorsi setelah pengelasan bilah ke-1, mm } & \multicolumn{3}{|c|}{ Distorsi setelah pengelasan bilah ke-8, mm } \\
\hline & Simulasi & Aktual & Deviasi & Simulasi & Aktual & Deviasi \\
\hline 1 (ref.) & 0,169 & 0,00 & 0,169 & 0,115 & 0,00 & 0,115 \\
\hline 2 & 0,343 & 0,5 & $-0,157$ & 0,171 & 0,30 & $-0,129$ \\
\hline 3 & 0,715 & 0,50 & 0,215 & 0,562 & 0,70 & $-0,138$ \\
\hline 4 & 1,143 & 0,95 & 0,193 & 0,929 & 0,80 & 0,129 \\
\hline 5 & 1,572 & 1,65 & $-0,078$ & 1,199 & 0,80 & 0,399 \\
\hline 6 & 1,957 & 2,00 & $-0,043$ & 1,362 & 1,32 & 0,042 \\
\hline 7 & 2,262 & 2,10 & 0,162 & 1,489 & 0,90 & 0,589 \\
\hline 8 & 2,439 & 2,50 & $-0,061$ & 1,787 & 1,70 & 0,087 \\
\hline 9 & 2,447 & 2,80 & $-0,353$ & 2,055 & 2,70 & $-0,645$ \\
\hline 10 & 2,47 & 2,75 & $-0,28$ & 2,087 & 2,30 & $-0,213$ \\
\hline 11 & 2,316 & 2,25 & 0,066 & 1,882 & 1,60 & 0,282 \\
\hline 12 & 2,012 & 1,90 & 0,112 & 1,493 & 1,20 & 0,293 \\
\hline 13 & 1,615 & 1,80 & $-0,185$ & 1,082 & 0,90 & 0,182 \\
\hline 14 & 1,175 & 1,20 & $-0,025$ & 0,705 & 1,00 & $-0,295$ \\
\hline 15 & 0,723 & 0,45 & 0,273 & 0,329 & 1,00 & $-0,671$ \\
\hline 16 & 0,294 & 0,10 & 0,194 & 0.0264 & 0,00 & 0,0264 \\
\hline
\end{tabular}

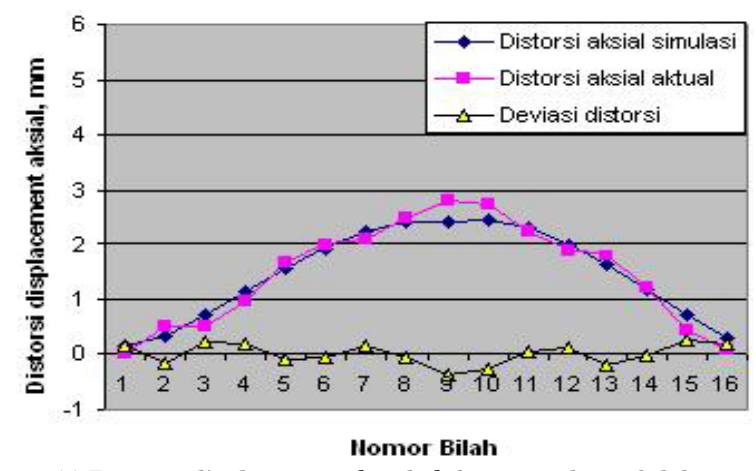

(a) Distorsi displacement aksial akibat pengelasan bilah 1

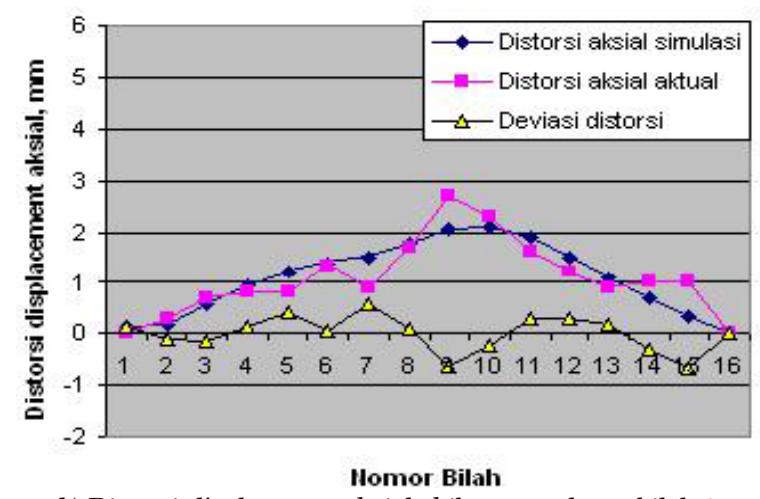

(b) Distorsi displacement aksial akibat pengelasan bilah 8

Gambar 13. Plot Distorsi Pengelasan Hasil Simulasi dan Pengukuran

Selain itu, Gambar 15 juga memperlihatkan grafik nilai distorsi displacement arah aksial antara simulasi dan hasil pengukuran langsung (aktual) mempunyai kecenderungan yang sama. Serta besarnya deviasi distorsi aksial simulasi dan aktual adalah kecil. Berdasarkan hasil ini dapat disimpulkan bahwa hasil simulasi cukup akurat untuk memprediksi distorsi displacement ketika urutan pengelasan bilah roda traktor diatur.

\section{Simulasi Pemodelan Urutan Pengelasan tidak Serial}

Dalam penelitian ini, salah satu metode yang direkomendasikan oleh Faure [8] untuk mencari urutan pengelasan diterapan pada simulasi, yaitu dengan melihat kecenderungan perubahan bentuk (distorsi). Dengan melakukan counter-act distorsi pada suatu titik, bentuk model diperkiraan akan kembali menuju kondisi semula. Ilustrasi penerapan metode ini untuk mencari urutan pengelasan bilah traktor yang baik dapat dilihat pada Gambar 14 . Seperti terlihat dalam gambar, daerah counter-act dipilih berdasarkan distorsi displacement roda maksimum. Perubahan bentuk sampai pengelasan bilah keempat dibentuk menuju kondisi semula dengan melakukan pengelasan pada daerah counter-act yang dipilih.

Gambar 15 memperlihatkan model urutan pengelasan tidak serial yang direkomendasikan berdasarkan simulasi. Pengelasan dimulai dengan pemasangan bilah kesatu, disusul dengan bilah kedua pada sisi seberang bilah kesatu dan seterusnya dengan urutan seperti dilihat pada Gambar 15.

Perbandingan distorsi displacement pengelasan serial dan tidak serial

Gambar 16 memperlihatkan perbandingan contoh model perubahan bentuk atau deformasi dari simulasi pengelasan bilah roda traktor dengan urutan serial dan tidak serial (seperti pada Gambar 15). Dari Gambar 16 dapat dilihat bahwa pada pengelasan sampai bilah ketiga, bentuk distorsi displacement radial (ketidakbulatan roda) dan aksial akibat pengelasan serial adalah lebih besar dibandingkan bentuk distorsi itu karena pengelasan tidak serial. Hasil dengan kecenderungan yang sama juga terjadi pada pengelasan sampai bilah ke6 dan ke-16 (bilah terakhir). 


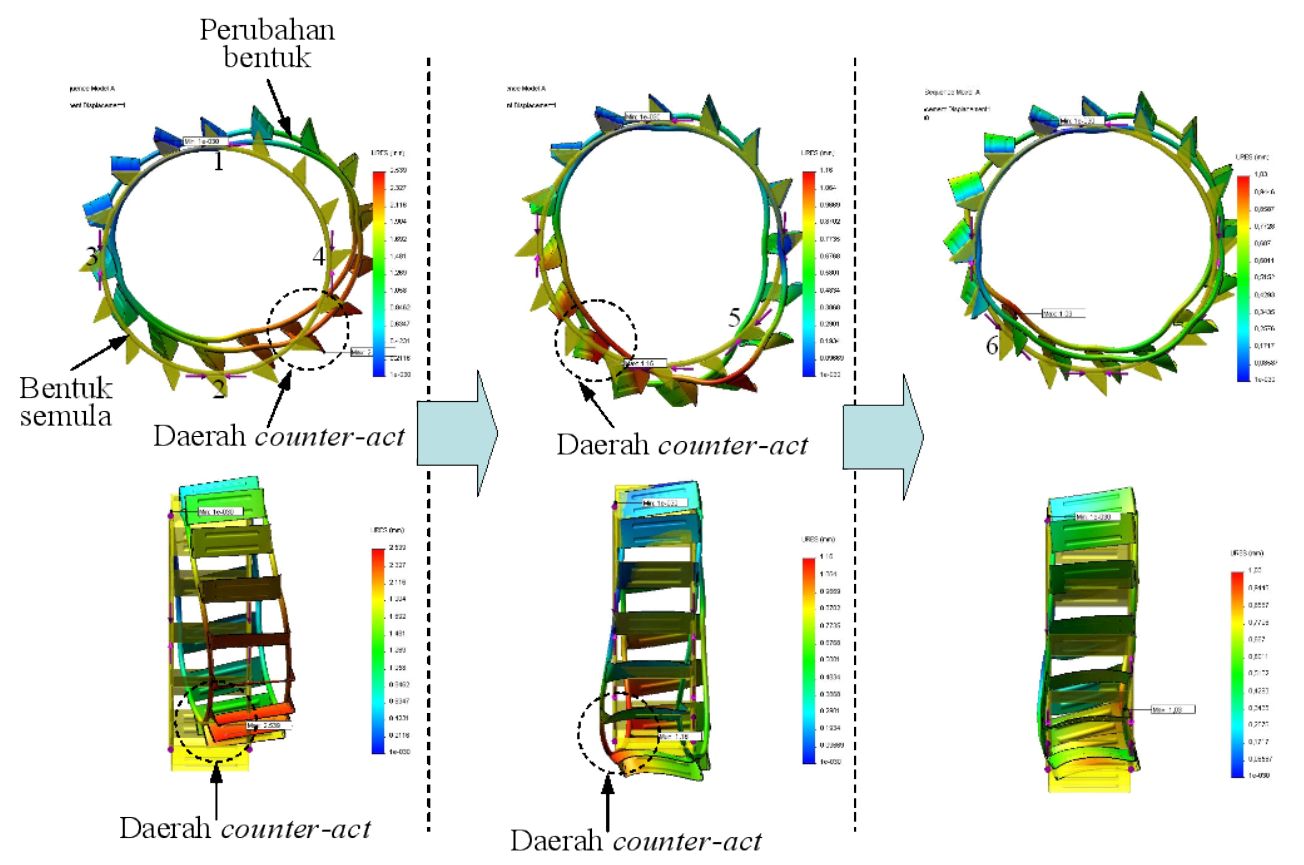

Keterangan:

$1,2,3,4,5$, dan $6=$ Urutan pengelasan bilah

Gambar 14. Ilustrasi Mencari Urutan Pengelasan Bilah Berdasarkan Metode Counter-act

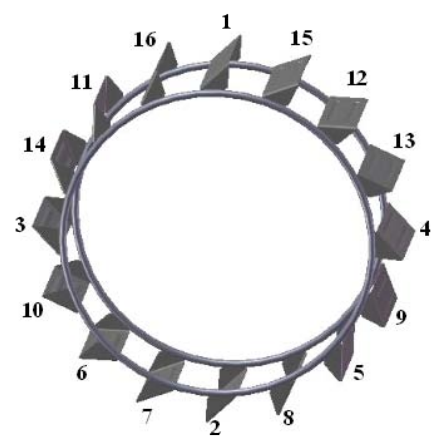

Gambar 15. Urutan Pengelasan Bilah Roda Traktor Secara Tidak Seri (direkomendasikan)

Pengelasan bilah ke-3

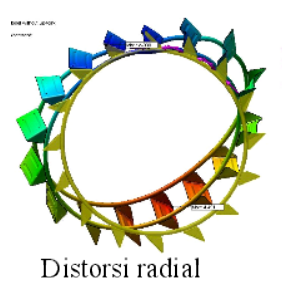

Distorsi radial

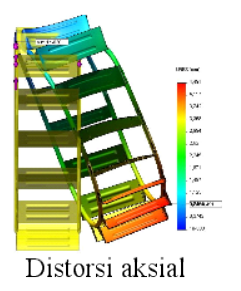

(a) Bentuk distorsi displacement akibat pengelasan serial bilah roda traktor
Pengelasan bilah ke-16
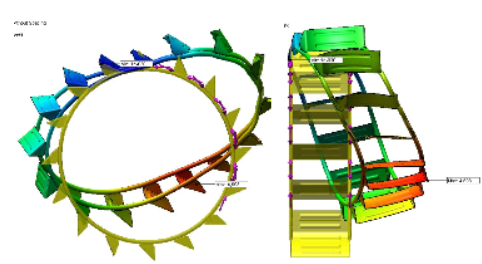

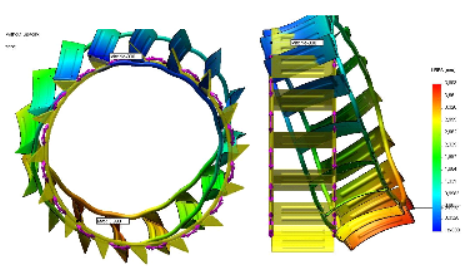

Pengelasan bilah ke-3

Pengelasan bilah ke-6

Pengelasan bilah ke-16
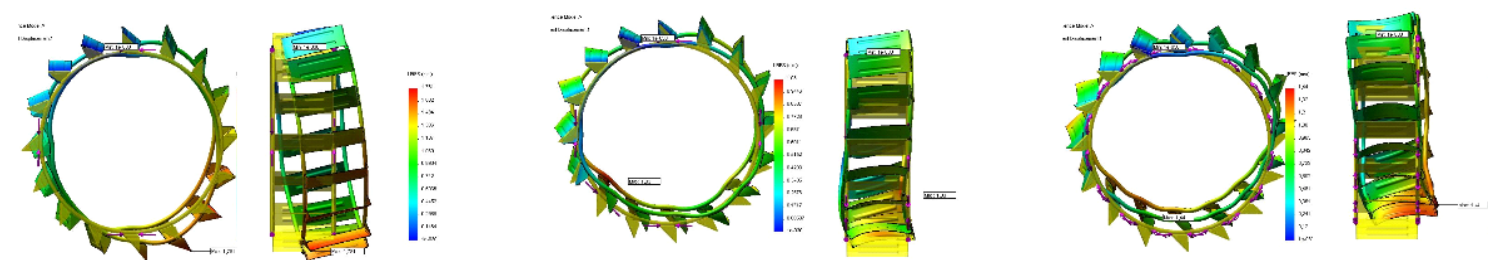

(b) Bentuk distorsi displacement akibat pengelasan tidak serial bilah roda traktor

Gambar 16. Perbandingan Bentuk Distorsi antara Pengelasan Serial dan Tidak Serial 

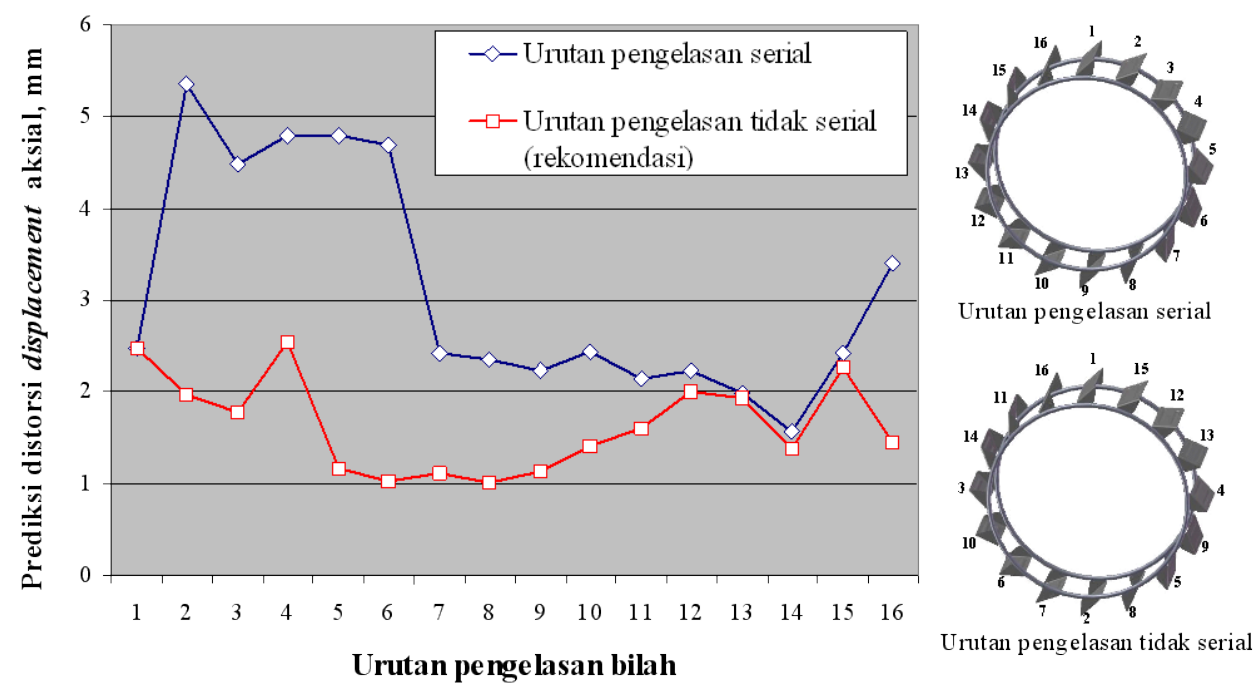

\section{Gambar 17. Perbandingan Distorsi Akibat Urutan Pengelasan Serial dan Tidak Serial}

Gambar 17 memperlihatkan grafik nilai prediksi distorsi displacement arah aksial akibat pengelasan diurut serial dan tidak serial. Dari gambar ini dapat dilihat bahwa nilai distorsi displacement aksial pada pengelasan bilah dengan urutan tidak serial adalah lebih kecil dibandingkan dengan nilai distorsi aksial karena pengelasan bilah dengan urutan serial. Pada pengelasan bilah dengan urutan tidak serial, nilai distorsi aksialnya adalah diprediksi sebesar 1,440 mm dibandingkan 3,393 $\mathrm{mm}$ pada pengelasan bilah dengan urutan serial.

\section{KESIMPULAN}

Dari penelitian tentang simulasi pemodelan urutan pengelasan bilah roda traktor yang dilakukan dapat disimpulkan beberapa hal sebagai verikut:

Dari hasil verifikasi diperoleh bahwa bentuk deformasi pengelasan antara simulasi dan eksperimen adalah mirip. Serta deviasi nilai distorsi displacement antara simulasi dan eksperimen adalah kecil. Hasil ini menjadi alasan bahwa simulasi pemodelan deformasi pengelasan menggunakan metode termal elasto-plastis dapat digunakan untuk memprediksi distorsi displacement akibat proses pengelasan bilah roda traktor.

Berdasarkan visualisasi hasil simulasi, bentuk distorsi displacement radial dan aksial akibat pengelasan bilah dengan urutan serial adalah lebih besar dibandingan bentuk distorsi itu karena pengelasan bilah yang tidak serial atau urutan pengelasan bilah yang direkomendasian dalam penelitian ini.

Hasil simulasi pada pengelasan 16 (enambelas) buah bilah roda traktor diperoleh nilai distorsi displacement terbesar akibat deformasi terjadi pada pengelasan bilah dengan urutan serial, yaitu sebesar 3,393 mm, dimana adalah nilai ini lebih besar dibandingkan nilai displacement $(1,440 \mathrm{~mm})$ pada pengelasan bilah dengan urutan seperti yang direkomendasikan dalam penelitian ini.

\section{Ucapan Terima Kasih}

Penulis mengucapkan terima kasih kepada Direktorat Penelitian dan Pengabdian kepada Masyarakat, DIKTI, Kementerian Pendidikan Nasional Republik Indonesia yang telah membiayai penelitian ini melalui Program Hibah Penelitian Hi-Link 2010.

\section{DAFTAR PUSTAKA}

1 Murakawa, H., Luo, Y., dan Ueda, Y., "Prediction of Welding Deformation and Residual Stress by Elastic FEM Based on Inherent Strain Production", Journal of the Society of Naval Architechs of Japan, Vol. 180, hal. 793-751, 1996.

2 Harun, S., et al., "Sinergitas Perencanaan Pengembangan Industri Kecil Logam Provinsi Lampung Melalui Diversifikasi Produk Logam dengan Menggunakan Metode Net Shape Manufacturing Dalam Rangka Meningkatkan Daya Saing dan Mutu Produk", Laporan Penelitian Hibah Hi-Link Tahun Pertama, DP2M Dikti, 2010.

3 Burst, F.W., dan Paul, S., "Weld Distortion Control Methods and Application of Weld Modelling", Transaction SmiRT 19, Toronto, 2007.

4 Rosenthal, D., "Mathematical theory of heat distribution during welding and cutting", Welding Journal 20(5): hal. 220-234, 1941.

5 Jeong,S. K., dan Cho, H. S., "An analytical solution to predict the transient temperature distribution in fillet arc welds", Welding Journal, 76 (6), hal. 223-232, 1997. 
6 Goldak, J.A., dan Akhlaghi, M., "Computational Welding Mechanics", Springer Science, New York, 2005.

7 Murakawa, H., Deng, D., Rashed, S., dan Sato, S., "Prediction of Distortion Produced on Welded Structures during Assembly Using Inherent
Deformation and Interface Element" Trans. JWRI, Vol. 38 No. 2, hal. 63-69, 2009.

8 Faure, W.C.,"Welding Fabrication and Metal Work, Welding and Fabrication", Bloemfontein, South Africa. 